\title{
Saliva levels of Abeta1-42 as potential biomarker of Alzheimer's disease: a pilot study
}

Felix Bermejo-Pareja ${ }^{1,2}$, Desiree Antequera ${ }^{2,3}$, Teo Vargas ${ }^{2,3}$, Jose A Molina ${ }^{1,2}$, Eva Carro ${ }^{2,3^{*}}$

\begin{abstract}
Background: Simple, non-invasive tests for early detection of degenerative dementia by use of biomarkers are urgently required. However, up to the present, no validated extracerebral diagnostic markers for the early diagnosis of Alzheimer disease (AD) are available. The clinical diagnosis of probable AD is made with around $90 \%$ accuracy using modern clinical, neuropsychological and imaging methods. A biochemical marker that would support the clinical diagnosis and distinguish AD from other causes of dementia would therefore be of great value as a screening test. A total of 126 samples were obtained from subjects with $A D$, and age-sex-matched controls. Additionally, 51 Parkinson's disease (PD) patients were used as an example of another neurodegenerative disorder. We analyzed saliva and plasma levels of $\beta$ amyloid (A $\beta$ ) using a highly sensitive ELISA kit.

Results: We found a small but statistically significant increase in saliva $A \beta_{42}$ levels in mild $A D$ patients. In addition, there were not differences in saliva concentration of $A \beta_{42}$ between patients with PD and healthy controls. Saliva $A \beta_{40}$ expression was unchanged within all the studied sample. The association between saliva $A \beta_{42}$ levels and $A D$ was independent of established risk factors, including age or Apo E, but was dependent on sex and functional capacity.

Conclusions: We suggest that saliva $A \beta_{42}$ levels could be considered a potential peripheral marker of $A D$ and help discrimination from other types of neurodegenerative disorders. We propose a new and promising biomarker for early AD.
\end{abstract}

\section{Background}

With increasing life expectancy across the world, Alzheimer's disease (AD), the most common cause of dementia, is a rapidly growing socioeconomic and medical problem. AD diagnosis is time consuming and requires a combination of clinical assessment, psychological testing, imaging and exclusion of other neurological disorders. In light of these facts, a molecular biomarker that could identify and classify AD would be particularly useful in order to confirm the diagnosis, to perform epidemiological screening, to identify distinct groups of patients, to predict the outcome of the disease, and to monitor its progression and its sensitivity to treatment. In fact, lack of tools to detect preclinical AD has been suggested to be one of the main obstacles for the development of new treatments [1]. The ideal biomarker for

\footnotetext{
* Correspondence: carroeva@yahoo.es

${ }^{2}$ Neurodegenerative Diseases Biomedical Research Center (CIBERNED),

Madrid, Spain

Full list of author information is available at the end of the article
}

AD should detect a fundamental feature of neuropathology: it should be as sensitive and specific as the clinical diagnosis, reliable, reproducible, simple to perform, inexpensive and non-invasive (studies on blood, urine, saliva, or buccal scrapings). Moderately invasive tests (skin, rectal biopsies, bone marrow samples, or cerebrospinal fluid -CSF-) or cerebral biopsy, are inconvenient for routine clinical practice.

In humans, in addition to the classical accumulation in the brain, amyloid-beta protein $(\mathrm{A} \beta)$ deposits are found in peripheral regions, including skin [2], nasal mucosa [3], and the lacrimal [4], and lingual glands [5]. The use of human salivary gland biopsies has been recently described as a tool for research on familial amyloidotic polyneuropathy (FAD) [6], and on AD [7] because both amyloid precursor protein (APP) and $A \beta$ are expressed in human salivary epithelial cells [7]. Saliva is produced from salivary glands and mucous membranes and, as a biological fluid, is simple to obtain. Additionally, salivary levels may reflect changes in CSF 
[8]. Recent studies showed association of activity and levels of salivary acetylcholinesterase (AChE) with AD [9]. These findings may prove to be a useful marker of central cholinergic activity which is a key event in the biochemistry of AD.

The majority of the studies of accepted AD biomarkers to date have been carried out using samples of CSF obtained by lumbar puncture [10]. This is an invasive procedure that is particularly unpleasant for the subject and for which explicit consent is required. Recently, it has been shown that identification of blood biomarkers may allow the development of tests for $\mathrm{AD}[11,12]$. In this study, we report that significant and reproducible levels of salivary $A \beta_{42}$ can be detected in subjects and there is a specific correlation with development of $\mathrm{AD}$ pathology.

\section{Methods \\ Subjects}

The study included three groups: (1) 70 Alzheimer's disease (AD); (2) 56 elderly nondemented controls without neurological disease or cognitive impairment; and (3) 51 Parkinson's disease (PD) patients. All AD cases included in these series were diagnosed with dementia according to the Diagnostic and Statistical Manual of Mental Disorders (DSM)-IV criteria [13], and NINCDS-ADRDA criteria [14], and diagnosis required evidence of cognitive decline, (neuropsychological test battery, clinical mental examination) as well as evidence of impairment in social or occupational function. The mini-mental state examination (MMSE) was used to assess cognitive function [15]. The mean value of MMSE score for the AD patients was 17. All cases had an extensive biochemical measurement including levels of vitamin $B_{12}$ and folate and thyroid hormones and neuroimaging techniques (brain MRI and/or CT scan). Classification of mild, moderate and severe degrees of AD was performed, and the diagnosis of vascular dementia was excluded in all cases, using DSM-III-R criteria. The control group was formed of family members or caregivers of the AD patients, who all had a clinical interview with a senior neurologist that showed a completely normal cognitive and functional level. No formal neuropsychological battery was performed in this group. PD group was formed of patients who had been diagnosed under the criteria of probable PD $[16,17]$. Demographic and health characteristics of the final sample $(n=136)$ are presented (table 1).

\section{Saliva and blood collection}

This study was approved by the Ethic Committee of Clinical Investigation of the Hospital ' 12 de Octubre'. Informed consent from all subjects was obtained prior to their participation Saliva samples were obtained from
Table 1 Demographic and health characteristics of the final sample $(n=136)$

\begin{tabular}{llccc}
\hline & Mean age & $\begin{array}{c}\text { Sex } \\
\text { Men/ } \\
\text { Women }\end{array}$ & $\begin{array}{l}\text { Mean } \\
\text { MMSE } \\
\text { (range) }\end{array}$ & $\begin{array}{c}\text { Mean } \\
\text { onset } \\
\text { (range) }\end{array}$ \\
\hline AD patients & $\begin{array}{l}77.20(60- \\
91)\end{array}$ & $21 / 49$ & $17(4-28)$ & $2.56(0-12)$ \\
PD patients & $\begin{array}{l}72.96(60- \\
\text { 93) }\end{array}$ & $26 / 25$ & $28(22-30)$ & $3.8(1-5)$ \\
Control & $74.35(64-$ & $17 / 39$ & nd & \\
subjects & $85)$ & & & \\
\hline
\end{tabular}

MMSE = mini-mental state examination; $\mathrm{AD}=$ Alzheimer's disease; $\mathrm{PD}=$ Parkinson's disease; nd $=$ not determined.

both healthy volunteers and patients with $\mathrm{AD}$ and $\mathrm{PD}$ and the study was carried out with full ethical permission. Saliva samples were collected in sterile plastic containers previously treated with $2 \%$ sodium azide solution, a concentration which has been shown to be sufficient to prevent microbial decomposition of saliva [18]. Participants were asked to wait at least 4 hours after eating or drinking (initiated at approximately the same time for each participant (13:00 hours), before providing saliva samples of approximately $1 \mathrm{ml}$ into the containers, and these were centrifuged at $1500 \mathrm{rpm}$ for 5 minutes to remove debris, in a similar manner to that previously described [19]. Then, the samples were immediately frozen at $-80^{\circ} \mathrm{C}$ until used. Blood samples were obtained through antecubital vein puncture. Blood was centrifuged at $2500 \mathrm{rpm}$ for 10 minutes, and plasma was collected, aliquoted and immediately frozen at $-80^{\circ} \mathrm{C}$. Cellular fraction was used for DNA extraction and genotyping assays.

\section{Apo E genotyping}

Apo E genotypes of AD and control subjects were determined by established methods as described previously [20]. Genomic DNA was extracted from peripheral blood using Illustra ${ }^{\mathrm{mm}}$ blood genomicPrep Mini Spin Kit (GE Healthcare). Apo E genotyping ( $\varepsilon 2 / \varepsilon 3 / \varepsilon 4$ isoforms) was performed using FRET probes.

\section{Immunoassays}

$30 \mu \mathrm{l}$ of saliva sample was mixed with an equal volume of $2 \times$ SDS sample buffer and denatured by heating at $95^{\circ} \mathrm{C}$ for 5 minutes. All samples were resolved by $10 \%$ SDS-polyacrylamide gel electrophoresis and transferred to nitrocellulose membranes (Bio-Rad) by electroblotting as previously described [21]. The following antibodies were used: mouse monoclonal anti-gelsolin (SigmaAldrich), rabbit polyclonal anti-TTR (Santa Cruz Biotechnology), goat anti-mouse HRP-conjugated (Bio-Rad), and goat anti-rabbit HRP-conjugated (Bio-Rad). Peroxidase-labeled lectin (Sigma) was used as gel loading control. Densitometric analysis was performed using ImageJ software (NIH Image). 
Levels of human endogenous $A \beta_{40}$ and $A \beta_{42}$ in saliva and human plasma samples were determined with human specific enzyme-linked immunosorbent assay (ELISA) (Biosource International, Invitrogen), according to the manufacturer's instructions and as previously described [22]. $50 \mu \mathrm{l}$ of saliva and plasma samples were added in duplicate to the microtiter wells. Detection limit of the assay was $6 \mathrm{pg} / \mathrm{ml}$ for $\mathrm{A} \beta_{40}$ and $1 \mathrm{pg} / \mathrm{ml}$ for $\mathrm{A} \beta_{42}$.

Previous to the immunoassays, protein concentration was assessed using a Spectrophotometer NanoDrop ND1000 , to normalize sample protein levels.

\section{Statistical analysis}

Data were analysed with SPSS for Windows (version 15.0). To compare demographic, clinical, and saliva and plasma data between groups, we used ANOVA followed by a Tuckey-Kramer test, and Mann-Whitney $U$-test analysis when appropriate. The differences were considered to be significant at $\mathrm{p}<0.05$. The Spearman rank correlation was used for correlation analyses.

\section{Results}

177 patients with $\mathrm{AD}, \mathrm{PD}$ and aged controls were assessed, and $A \beta_{40}$ and $A \beta_{42}$ levels were measured in saliva from these patients using a sensitive and specific $A \beta$ ELISA. It is particularly relevant that we were able to detect $A \beta_{40}$ and $A \beta_{42}$ in human saliva by a simple and reproducible method. The groups did not differ significantly by age or sex. Our findings show that saliva concentration of $A \beta_{42}$ has a tendency to increase in $A D$ patients compared with PD and control groups, but this effect was not statistically significant. Interestingly, when we analyzed the three categories of AD patients, we found that saliva $A \beta_{42}$ levels were significantly increased in the first category of AD patients [in mild AD stage ( $\mathrm{p}$ $=0.043$, and table 2)], whereas saliva $A \beta_{42}$ levels in moderate $\mathrm{AD}$ stage are also increased but with a high standard deviation (SD). Interestingly, the third category of $\mathrm{AD}$, the severe AD stage, has similar than those observed in control group (table 2). Age range was similar between all AD stages and the control group. A $2 \times$

Table 2 Saliva $A \beta_{42}$ levels in patients with neurodegenerative diseases and control subjects

\begin{tabular}{lccc}
\hline Group & $\mathbf{A} \boldsymbol{\beta}_{\mathbf{4 2}}(\mathbf{p g} / \mathbf{m l})$ & $\mathbf{A} \boldsymbol{\beta}_{\mathbf{4 0}}(\mathbf{p g} / \mathbf{m l})$ & No. of subjects \\
\hline AD patients & $\mathbf{6 . 8 1} \pm \mathbf{2 0 . 0 4}$ & $\mathbf{2 2 . 3} \pm \mathbf{4 . 8 8}$ & 70 \\
$\quad$ Mild & $7.67 \pm 16.25^{*}$ & $21.87 \pm 5.7$ & 29 \\
$\quad$ Moderate & $11.70 \pm 34.76$ & $21.5 \pm 4.17$ & 24 \\
$\quad$ Severe & $3.03 \pm 3.49$ & $23.92 \pm 4.55$ & 17 \\
PD patients & $3.66 \pm 4.21$ & $26.41 \pm 5.12$ & 51 \\
Control subjects & $2.89 \pm 4.96$ & $20.82 \pm 5.55$ & 56 \\
\hline
\end{tabular}

$\mathrm{AD}=$ Alzheimer's disease; $\mathrm{PD}=$ Parkinson's disease. Values are mean $\pm \mathrm{SD}$. *p $<0.05$ versus control subjects
2 contingency table analysis, with a cut-off $=7.85 \mathrm{pg} /$ $\mathrm{ml}$, allowed the calculation of sensitivity and specificity (defined as the proportion of true positive and the portion of true negative that are correctly identified by the test, respectively). The results were $16 \%$ and $93 \%$, respectively. In addition, we performed ROC curve analysis, with 0.547 (area under the curve) AUC (95\% CI 0.4-0.68). On the other hand, $A \beta_{40}$ was unchanged between $\mathrm{AD}$ patients and healthy subjects (table 2). We also analyzed the ratio between saliva $A \beta_{42}$ and $A \beta_{40}$ and we found that this ratio was higher, but not statistically significant $(p=0.2)$, in mild and moderate AD patients ( 0.35 and 0.54 , respectively) in compared with control subject $(0.13)$, whereas it was unchanged in severe AD patients (0.12).

\section{Overall, saliva $A \beta_{42}$ levels were not significantly higher with age}

However, comparison of AD patients aged 60-65 with those aged 66-70 showed highly significant elevation in saliva $\mathrm{A} \beta_{42}$ levels $(1.64 \pm 0.44 \mathrm{pg} / \mathrm{ml}$ versus $6.46 \pm 3.43$ $\mathrm{pg} / \mathrm{ml}, \mathrm{p}=0.016$ ).

In addition, plasma levels of $A \beta_{40}$ and $A \beta_{42}$ did not differ significantly between patients with $\mathrm{AD}$ and control subjects $(259 \pm 91.9 \mathrm{pg} / \mathrm{ml}$ versus $225.1 \pm 77.3 \mathrm{pg} / \mathrm{ml}$, and $42.4 \pm 92.7 \mathrm{pg} / \mathrm{ml}$ versus $52.4 \pm 68.9 \mathrm{pg} / \mathrm{ml}$, respectively), in accordance with recent studies [23]. Spearman rank analysis of plasma and saliva levels was not significant for either $A \beta_{40}$ or $A \beta_{42}$ levels.

To determine whether the elevated saliva $A \beta_{42}$ was associated with the Apo E \&4 allele, all subjects were genotyped for $A p o E$ and their $A \beta_{42}$ levels were analyzed according to the ApoE genotypes. The Apo E $\varepsilon 4$ allele frequencies were $45 \%$ (15 with Apo E $83 / 4$ genotype and 3 with Apo E $\varepsilon 4 / 4$ genotype) in the AD group and $12 \%$ (3 with Apo E $\varepsilon 3 / 4$ genotype and 1 with Apo E $\varepsilon 2 / 4$ genotype) in the control group. Firstly, we found that ApoE genotype correlates with AD onset (Spearman rank correlation $R=0.428, p=0.001$ ). Levels of $A \beta_{42}$ were higher, but not statistically significantly, in patients with $\mathrm{AD}$ and without the Apo $\mathrm{E} \varepsilon 4$ allele than in those

Table 3 Saliva $A \beta_{42}$ levels in patients with $A D$ and control subjects

\begin{tabular}{lccc}
\hline Group & No. Of subjects & Age & $\mathbf{A} \boldsymbol{\beta}_{\mathbf{4 2}}(\mathbf{p g} / \mathbf{m l})$ \\
\hline AD patients & 38 & & \\
With Apo E $\varepsilon 4$ & 18 & $75.18 \pm 7.91$ & $6.42 \pm 15.48$ \\
Without Apo E $\varepsilon 4$ & 20 & $75.05 \pm 8.85$ & $12.52 \pm 33.58$ \\
Control subjects & 34 & & \\
With Apo E $\varepsilon 4$ & 4 & $68.5 \pm 8.70$ & $2.05 \pm 1.48$ \\
Without Apo E $\varepsilon 4$ & 30 & $69.10 \pm 9.25$ & $2.51 \pm 2.61$ \\
\hline
\end{tabular}

Data are mean $\pm S D ; A D=$ Alzheimer's disease. 
with the allele (table 3). Levels of $A \beta_{42}$ were similar in controls with and without Apo E $\varepsilon 4$ allele (table 3).

To test that protein changes are specific to $A \beta_{42}$ levels, we measured protein concentration in saliva samples from all experimental groups. We did not find significant differences between groups $(6.39 \pm 3.68 \mathrm{ng} / \mu \mathrm{l}$ in aged subjects, $6.49 \pm 4.79 \mathrm{ng} / \mu \mathrm{l}$ in $\mathrm{AD}$ patients, and $6.67 \pm 5.71 \mathrm{ng} / \mu \mathrm{l}$ in PD patients, data are expressed as mean \pm SEM). Additionally, we tested others protein concentrations in these saliva samples. We choose two proteins with $A \beta$-carrier function, gelsolin, and transthyretin. Using Western-blot assays, we did not observe an alteration in gelsolin (figure 1a) and transthyretin (figure 1b) expression in AD patients compared with control subjects. These results support our finding in human saliva that $A \beta_{42}$ levels are closely associated with AD diagnosis.

Demographic risk factors could modify the association between pathological saliva $A \beta_{42}$ and progression to $A D$. One of the studied variables was MMSE score. Mean MMSE score of AD patients was 17 (range 4-28) (table 1 ), and correlates with the three categories of $\mathrm{AD}$ (Spearman rank correlation $\mathrm{R}=-0.763, \mathrm{p}=0.001$ ). The relationship between these variables was similar for males or females. Other studied risk factors in the AD group were: hypertension (with a prevalence of 47.1\%), hypercholesterol (10\%), arthritis (20\%), depression (20\%), diabetes (12.9\%), and heart disease (15.7\%). We analyzed whether there was an association between these risk factors and saliva $A \beta_{42}$ levels. With MannWhitney $U$-test analysis, we found that the concentration of saliva $A \beta_{42}$ correlates with sex (95\% CI 0.71 $2.29, \mathrm{p}=0.002)$ in the $\mathrm{AD}$ group.

\section{Discussion}

Early diagnosis of AD represents a primary goal, and the role of biomarkers seems to be crucial in a routine clinical setting. The main findings of this study are that saliva $A \beta_{42}$ levels are significantly elevated in early stage AD patients in comparison to control subjects, and we suggest that this effect is specific to $A D$ and not to other neurodegenerative disorders, including PD. These data result in a slightly higher specificity, and suggest that measuring saliva $A \beta_{42}$ may be used as biomarker to identify and confirm early $A D$ diagnosis.
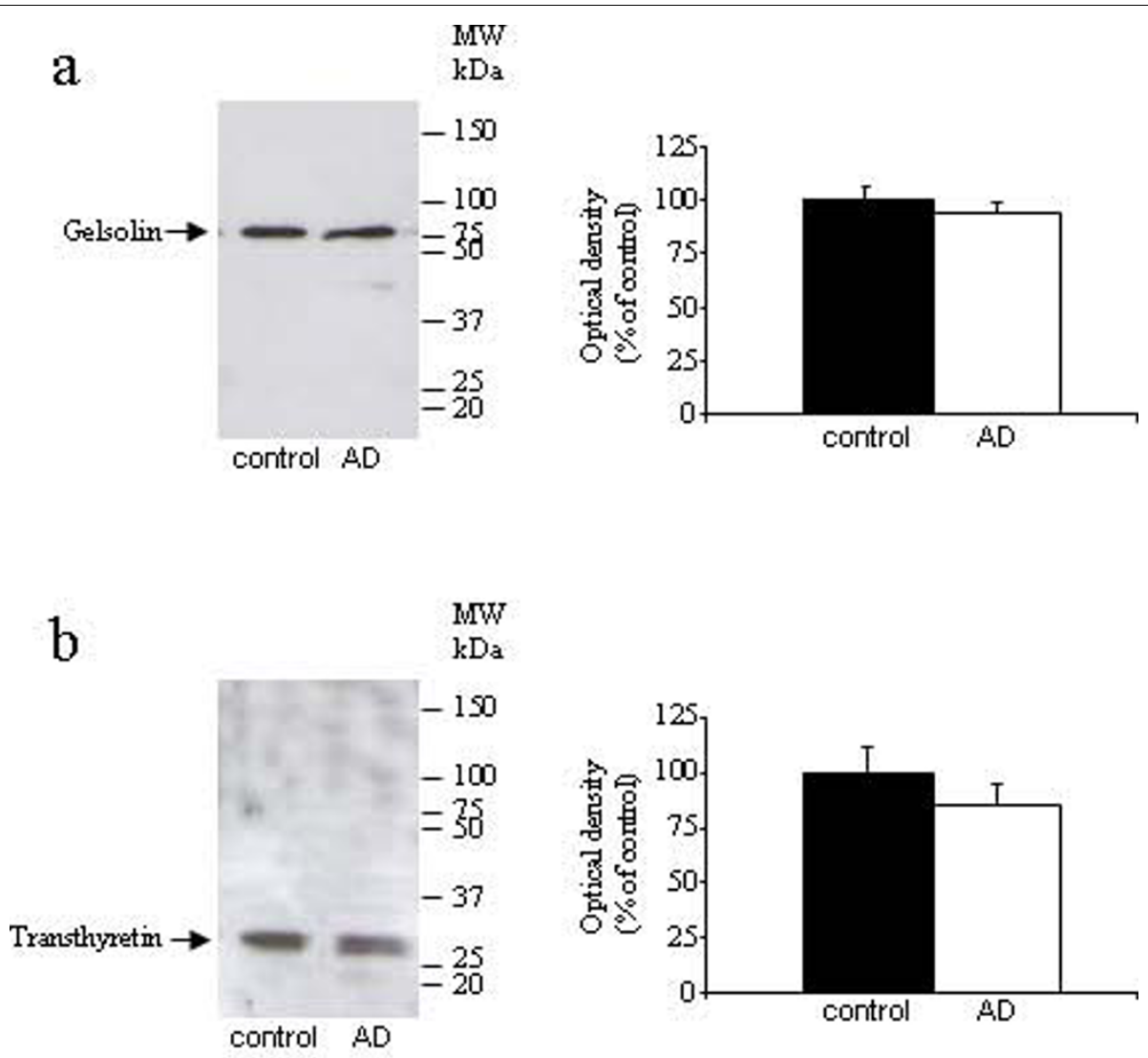

Figure 1 Western-blot analysis of saliva levels of gelsolin (a) and transthyretin (b) in AD and control groups ( $n=41-44$ per group). Figures shows representative blots and quantitative from 4 independent measurements. 
Biomarkers are required to improve the diagnostic sensitivity and specificity and to monitor the biological activity of AD in terms of the burden of neuronal involvement and the rate of disease progression. They must initially supplement our more traditional neuropsychological and imaging markers and may progress to provide useful tool to test the pharmacological action of antidementia compounds $[24,25]$. The currently best validated CSF biomarkers, pTau and $\mathrm{A} \beta_{42}$, with a reported sensitivity and specificity of around $90-95 \%$ for the diagnosis of $\mathrm{AD}$, show generally a good correlation with cerebral tau and $A \beta$ pathology [26-28]. As biomarkers in plasma several substances have been examined, but none of these markers had enough sensitivity or specificity to diagnose $\mathrm{AD}$ [24].

Saliva is frequently used to test for the levels of a number of hormones, and is considered as a non-invasive technique [29]. Therefore, the identification of robust and reproducible $A \beta_{42}$ expression in saliva is of particular importance as it may serve as a potential indicator of $\mathrm{AD}$ neuropathology that can be measured with the minimum of stress for the subject. The mechanism by which $A \beta_{42}$ accumulates in saliva is unclear. This localization could result from release of this peptide from salivary glands by APP processing as a consequence of secretase enzymes action in salivary epithelial cells [7]. Our data could reflect a similar situation to brain $A \beta$ generation. The vast majority of studies performed so far have reported an increased accumulation of $\mathrm{A} \beta_{42}$ in cerebral parenchyma, mainly as senile plaques [30], whereas $A \beta_{42}$ levels were reduced in CSF of patients with $\mathrm{AD}[31,32]$. The significance of saliva $\mathrm{A} \beta$ levels in relation to $A \beta$ accumulation in the brain is unknown; however, their concentrations are comparable with those observed from tissues other than brain, including lens [33]. Lower levels of CSF $A \beta_{42}$ in the AD group may be explained due to loss of neurons that produce the APP, brain A $\beta$ accumulation, and/or decreased $A \beta$ clearance, as a consequence of impaired blood-brain barrier. As, the latter is not present in salivary glands, $A \beta$ produced from APP glands may be delivered and accumulated in the saliva, mainly in mild AD patients, whereas, in severe $A D$ stage, saliva $A \beta_{42}$ levels return to control values. This pattern may reflect a parallelism with CSF $A \beta_{42}$ levels. The association of different combinations of saliva $A \beta$ levels with $A D$ was independent of established risk factors such as age or Apo E genotype, major risk factors for sporadic AD. However, we found a significant correlation between sex and saliva $\mathrm{A} \beta_{42}$ levels in patients with $\mathrm{AD}$. With several discrepancies, our data are consistent with previous studies using CSF and plasma samples [27,34]. Several studies had described no correlation between CSF A $\beta$ levels and dementia severity [27,34-36]. However, others showed weak [37], or strong [38] correlation between these variables. In our study, we showed no significant relationship between saliva $A \beta_{42}$ levels and MMSE scores, however when we analyzed the three categories of $\mathrm{AD}$ patients, accordingly with the functional capacity, we found a significant correlation. Thus, large and longitudinal studies with a greater number of samples will be necessary to determine conclusively whether there is a relationship between saliva $A \beta_{42}$ levels and progression of $\mathrm{AD}$.

Decreased saliva production is common amongst elderly people, and in patients with $\mathrm{AD}$, salivary flow from the submandibular gland has been found to be significantly impaired [39]. However, the protein concentration of the saliva samples obtained from the elderly control subjects was similar to those of the subjects either with AD or PD. Additionally, we decided to investigate whether the concentration of other proteins may be changed in saliva samples from AD patients. $A \beta$ forms complexes with protein carriers, including transthyretin or gelsolin, to prevent peptide polymerization and aggregation [40-42]. Since these proteins are present in body fluids $[32,43]$, and are significantly reduced in CSF from AD patients $[32,44,45]$, we chose them to test our hypothesis. Since total protein concentration was similar in AD patients and healthy subjects, and these secreted proteins was unchanged in both groups, we may suggest that elevated $A \beta_{42}$ levels represent a specific change for $\mathrm{AD}$, and can not be attributed to a general increase in salivary protein concentration.

As usual, there were various difficulties in the measurement of $A \beta$ levels in body fluids. Additionally, $A \beta$ values decreased over time, even if the samples were frozen [46]. Although range of saliva $A \beta_{42}$ levels was high, we consider that is not in discrepancy with those reported in plasma or CSF samples from AD patients, with range seen from $100 \mathrm{pg} / \mathrm{ml}$ to $770 \mathrm{pg} / \mathrm{ml}$, and 25 $\mathrm{pg} / \mathrm{ml}$ to $325 \mathrm{pg} / \mathrm{ml}$, respectively [34]. In this study, we demonstrate the remarkable reproducibility of the saliva A $\beta$ ELISA in different series of repetitive measurements. It is particularly significant that saliva analyses of $A \beta_{42}$ are increased in mild AD patients, whereas in the severe stage, associated with a greater neurodegeneration, the levels are unchanged. Our data was supported by the ratio $A \beta_{42} / A \beta_{40}$ in saliva that was higher in mild and moderate $\mathrm{AD}$ patients in compared with control subject, whereas it was unchanged in severe AD patients. This fact is consistent with the main objective of AD biomarkers: the early diagnosis. Indeed, further studies will be performed to determine saliva $A \beta_{42}$ levels in mild cognitive impairment $(\mathrm{MCI})$, an intermediate stage to dementia, how these levels change across the transition from normal to MCI, and the interactions with age and Apo E genotype. If validated in other consecutive studies 
with long follow-up and large number of patients, these results may have an effect on diagnosis and on the design of clinical trials of patients with mild AD.

\section{Conclusions}

There were no significant differences in $A \beta_{42}$ levels between AD, PD and controls subjects. However, our findings show that saliva concentration of $A \beta_{42}$ differs between mild $\mathrm{AD}$ and non-demented control subjects, and that this is a specific characteristic of AD, being absent in PD. To our knowledge, no study to date has investigated the possibility of overlapping AD-associated $A \beta$ levels in saliva and brain of subjects with this disorder. Our results show that saliva analyses of $A \beta_{42}$ are powerful risk markers for development of clinical $\mathrm{AD}$ in patients.

\section{Acknowledgements \\ This work was supported by grants from Fondo de Investigación Sanitaria (FIS) (PI060155, Pl0901636), Fundación Investigación Médica Mutua Madrileña (2006.125), CIBERNED. This work was made possible by the generous participation of the patients, the control subjects, and their families. We thank Joe Healey for editorial revision, and Dr J Manzanares, who suggested the possible utility of the saliva study in the neurodegenerative disorders. \\ Author details \\ ${ }^{1}$ Neurology Service, Hospital 12 de Octubre, Madrid, Spain. \\ ${ }^{2}$ Neurodegenerative Diseases Biomedical Research Center (CIBERNED), Madrid, Spain. ${ }^{3}$ Neuroscience Laboratory, Research Center, Hospital 12 de Octubre, Madrid, Spain.}

\section{Authors' contributions}

FB-P: conceived of the study, provide clinical samples and diagnostic data, and participated in its design and coordination.

DA: carried out the immunoassays and performed the statistical analysis.

TV: carried out the molecular genetic studies.

JAM: provide clinical samples and diagnostic data.

EC: conceived of the study, participated in its design and coordination, and wrote the manuscript.

All authors read and approved the final manuscript.

Received: 8 July 2010 Accepted: 3 November 2010

Published: 3 November 2010

\section{References}

1. Lansbury PT Jr: Back to the future: the old-fashioned way to new medications for neurodegeneration. Nat Med 2004, 10:51-57.

2. Gasparini L, Racchi M, Binetti G, Trabucchi M, Solerte SB, Alkon D, Etcheberrigaray R, Gibson G, Blass J, Paoletti R, Govoni S: Peripheral markers in testing pathophysiological hypotheses and diagnosing Alzheimer's disease. FASEB J 1998, 12:17-34.

3. Attems J, Lintner $F$, Jellinger KA: Olfactory involvement in aging and Alzheimer's disease: an autopsy study. J Alzheimers Dis 2005, 7:149-157.

4. Frederikse $\mathrm{PH}$, Garland D, Zigler JS Jr, Piatigorsky J: Oxidative stress increases production of beta-amyloid precursor protein and betaamyloid (Abeta) in mammalian lenses, and Abeta has toxic effects on lens epithelial cells. J Biol Chem 1996, 271:10169-10174.

5. Fukuchi K, Li L, Hart M, Lindsey JR: Accumulation of amyloid-beta protein in exocrine glands of transgenic mice overexpressing a carboxyl terminal portion of amyloid protein precursor. Int J Exp Pathol 2000, 81:231-239.

6. Sousa MM, do Amaral JB, Guimarães A, Saraiva MJ: Up-regulation of the extracellular matrix remodeling genes, biglycan, neutrophil gelatinaseassociated lipocalin, and matrix metalloproteinase-9 in familial amyloid polyneuropathy. FASEB J 2005, 19:124-126.
7. Oh YS, Turner RJ: Effect of gamma-secretase inhibitors on muscarinic receptor-mediated calcium signaling in human salivary epithelial cells. Am J Physiol Cell Physiol 2006, 291:76-82.

8. Scherber A, Richter K, Schaps P: Distribution of antiepileptic drugs between plasma, plasma water, cerebrospinal fluid, saliva and brain. Monogr Neural Sci 1980, 5:208-212.

9. Sayer R, Law E, Connelly PJ, Breen KC: Association of a salivary acetylcholinesterase with Alzheimer's disease and response to cholinesterase inhibitors. Clin Biochem 2004, 37:98-104.

10. Blennow K, Hampel H: CSF markers for incipient Alzheimer's disease. Lancet Neurol 2003, 2:605-613.

11. Ray S, Britschgi M, Herbert C, Takeda-Uchimura Y, Boxer A, Blennow K, Friedman LF, Galasko DR, Jutel M, Karydas A, Kaye JA, Leszek J, Miller BL, Minthon L, Quinn JF, Rabinovici GD, Robinson WH, Sabbagh MN, So YT, Sparks DL, Tabaton M, Tinklenberg J, Yesavage JA, Tibshirani R, WyssCoray T: Classification and prediction of clinical Alzheimer's diagnosis based on plasma signaling proteins. Nat Med 2007, 13:1359-1362.

12. German DC, Gurnani P, Nandi A, Garner HR, Fisher W, Diaz-Arrastia R, O'Suilleabhain P, Rosenblatt KP: Serum biomarkers for Alzheimer's disease: proteomic discovery. Biomed Pharmacother 2007, 61:383-389.

13. American Psychiatric Association: DSM-IV. Diagnostic and Statistical Manual of Mental Disorders. Washington DC: American Psychiatric Association; 1994.

14. McKhann G, Drachman D, Folstein M, Katzman R, Price D, Stadlan EM: Clinical diagnosis of Alzheimer's disease: report of the NINCDS-ADRDA Work Group under the auspices of Department of Health and Human Services Task Force on Alzheimer's Disease. Neurology 1984, 34:939-944.

15. Folstein MF, Folstein SE, McHugh PR: "Mini-mental state". A practical method for grading the cognitive state of patients for the clinician. $J$ Psychiatr Res 1975, 12:189-198.

16. Calne DB, Snow BJ, Lee C: Criteria for diagnosing Parkinson's disease. Ann Neurol 1992, 32:125-127.

17. Gelb DJ, Oliver E, Gilman S: Diagnostic criteria for Parkinson disease. Arch Neurol 1999, 56:33-39.

18. Decker SA: Low salivary cortisol and elevated depressive affect among rural men in Botswana: reliability and validity of laboratory results. J Physiol Anthropol 2006, 25:91-101.

19. Boston PF, Gopalkaje K, Manning L, Middleton L, Loxley M: Developing a simple laboratory test for Alzheimer's disease: measuring acetylcholinesterase in saliva - a pilot study. Int J Geriatr Psychiatry 2008, 23:439-440.

20. Aslanidis C, Schmitz G: High-speed apolipoprotein E genotyping and apolipoprotein B3500 mutation detection using real-time fluorescence PCR and melting curves. Clin Chem 1999, 45:1094-1097.

21. Yao C, Karabasil MR, Purwanti N, Li X, Akamatsu T, Kanamori N, Hosoi K: Tissue kallikrein mK13 is a candidate processing enzyme for the precursor of interleukin-1beta in the submandibular gland of mice. J Biol Chem 2006, 281:7968-7976.

22. Lehman EJ, Kulnane LS, Gao Y, Petriello MC, Pimpis KM, Younkin L, Dolios G, Wang R, Younkin SG, Lamb BT: Genetic background regulates beta-amyloid precursor protein processing and beta-amyloid deposition in the mouse. Hum Mol Genet 2003, 12:2949-2956.

23. Xia W, Yang T, Shankar G, Smith IM, Shen Y, Walsh DM, Selkoe DJ: A specific enzyme-linked immunosorbent assay for measuring betaamyloid protein oligomers in human plasma and brain tissue of patients with Alzheimer disease. Arch Neurol 2009, 66:190-199.

24. Irizarry MC: Biomarkers of Alzheimer disease in plasma. NeuroRx 2004, 1:226-234.

25. Blennow K: CSF biomarkers for Alzheimer's disease: use in early diagnosis and evaluation of drug treatment. Expert Rev Mol Diagn 2005, 5:661-672

26. Buerger K, Ewers M, Pirttila T, Zinkowski R, Alafuzoff I, Teipel SJ, DeBernardis J, Kerkman D, McCulloch C, Soininen H, Hampel H: CSF phosphorylated tau protein correlates with neocortical neurofibrillary pathology in Alzheimer's disease. Brain 2006, 129:3035-3041.

27. Hansson O, Zetterberg H, Buchhave P, Londos E, Blennow K, Minthon L: Association between CSF biomarkers and incipient Alzheimer's disease in patients with mild cognitive impairment: a follow-up study. Lancet Neurol 2006, 5:228-234.

28. Buerger K, Alafuzoff I, Ewers M, Pirttila T, Zinkowski R, Hampel H: No correlation between CSF tau protein phosphorylated at threonine 181 
with neocortical neurofibrillary pathology in Alzheimer's disease. Brain 2007, 130:e82.

29. Cook CJ: Rapid noninvasive measurement of hormones in transdermal exudate and saliva. Physiol Behav 2002, 75:169-181.

30. Hardy J, Selkoe DJ: The amyloid hypothesis of Alzheimer's disease: progress and problems on the road to therapeutics. Science 2002, 297:353-356.

31. Sunderland $T$, Linker $G$, Mirza N, Putnam KT, Friedman DL, Kimmel LH, Bergeson J, Manetti GJ, Zimmermann M, Tang B, Bartko JJ, Cohen RM: Decreased beta-amyloid1-42 and increased tau levels in cerebrospinal fluid of patients with Alzheimer disease. JAMA 2003, 289:2094-2103.

32. Dietrich MO, Spuch C, Antequera D, Rodal I, de Yébenes JG, Molina JA, Bermejo F, Carro E: Megalin mediates the transport of leptin across the blood-CSF barrier. Neurobiol Aging 2008, 29:902-912.

33. Goldstein LE, Muffat JA, Cherny RA, Moir RD, Ericsson MH, Huang $X$, Mavros C, Coccia JA, Faget KY, Fitch KA, Masters CL, Tanzi RE, Chylack LT Jr, Bush Al: Cytosolic beta-amyloid deposition and supranuclear cataracts in lenses from people with Alzheimer's disease. Lancet 2003, 361:1258-1265.

34. Mehta PD, Pirttilä T, Mehta SP, Sersen EA, Aisen PS, Wisniewski HM: Plasma and cerebrospinal fluid levels of amyloid beta proteins 1-40 and 1-42 in Alzheimer disease. Arch Neurol 2000, 57:100-105.

35. Motter R, Vigo-Pelfrey C, Kholodenko D, Barbour R, Johnson-Wood K, Galasko D, Chang L, Miller B, Clark C, Green R: Reduction of beta-amyloid peptide 42 in the cerebrospinal fluid of patients with Alzheimer's disease. Ann Neurol 1995, 38:643-648.

36. Tamaoka A, Sawamura N, Fukushima T, Shoji S, Matsubara E, Shoji M, Hirai S, Furiya Y, Endoh R, Mori H: Amyloid beta protein 42(43) in cerebrospinal fluid of patients with Alzheimer's disease. J Neurol Sci 1997, 148:41-45.

37. Galasko D, Chang L, Motter R, Clark CM, Kaye J, Knopman D, Thomas R, Kholodenko D, Schenk D, Lieberburg I, Miller B, Green R, Basherad R, Kertiles L, Boss MA, Seubert P: High cerebrospinal fluid tau and low amyloid beta42 levels in the clinical diagnosis of Alzheimer disease and relation to apolipoprotein E genotype. Arch Neurol 1998, 55:937-945.

38. Samuels SC, Silverman JM, Marin DB, Peskind ER, Younki SG, Greenberg DA, Schnur E, Santoro J, Davis KL: CSF beta-amyloid, cognition, and APOE genotype in Alzheimer's disease. Neurology 1999, 52:547-551.

39. Ship JA, DeCarli C, Friedland RP, Baum BJ: Diminished submandibular salivary flow in dementia of the Alzheimer type. J Gerontol 1990, 45:61-66.

40. Chodobski A, Szmydynger-Chodobska J: Choroid plexus: target for polypeptides and site of their synthesis. Microsc Res Tech 2001, 52:65-82.

41. Carro E, Trejo JL, Gomez-Isla T, LeRoith D, Torres-Aleman I: Serum insulinlike growth factor I regulates brain amyloid-beta levels. Nat Med 2002, 8:1390-1397.

42. Ray I, Chauhan A, Wegiel J, Chauhan VP: Gelsolin inhibits the fibrillization of amyloid beta-protein, and also defibrillizes its preformed fibrils. Brain Res 2000, 853:344-351.

43. Kwiatkowski DJ, Stossel TP, Orkin SH, Mole JE, Colten HR, Yin HL: Plasma and cytoplasmic gelsolins are encoded by a single gene and contain a duplicated actin-binding domain. Nature 1986, 323:455-458.

44. Gloeckner SF, Meyne F, Wagner F, Heinemann U, Krasnianski A, Meissner B, Zerr I: Quantitative analysis of transthyretin, tau and amyloid-beta in patients with dementia. J Alzheimers Dis 2008, 14:17-25.

45. Antequera D, Vargas T, Ugalde C, Spuch C, Molina JA, Ferrer I, BermejoPareja F, Carro E: Cytoplasmic gelsolin increases mitochondrial activity and reduces $A \beta$ burden in a mouse model of Alzheimer's disease. Neurobiol Dis 2009, 36:42-50.

46. Southwick PC, Yamagata SK, Echols CL Jr, Higson GJ, Neynaber SA, Parson RE, Munroe WA: Assessment of amyloid beta protein in cerebrospinal fluid as an aid in the diagnosis of Alzheimer's disease. J Neurochem 1996, 66:259-265.

\section{Pre-publication history}

The pre-publication history for this paper can be accessed here: http://www.biomedcentral.com/1471-2377/10/108/prepub

doi:10.1186/1471-2377-10-108

Cite this article as: Bermejo-Pareja et al: Saliva levels of Abeta1-42 as potential biomarker of Alzheimer's disease: a pilot study. BMC Neurology 2010 10:108.

\section{Submit your next manuscript to BioMed Central and take full advantage of:}

- Convenient online submission

- Thorough peer review

- No space constraints or color figure charges

- Immediate publication on acceptance

- Inclusion in PubMed, CAS, Scopus and Google Scholar

- Research which is freely available for redistribution 